\title{
APPLICATION OF SHIELDING GASES IN WELDING PRODUCTION (REVIEW)
}

\author{
B.E. PATON, S.T. RIMSKY and V.I. GALINICH \\ E.O. Paton Electric Welding Institute, NASU \\ 11 Bozhenko Str., 03680, Kiev, Ukraine. E-mail: office@paton.kiev.ua
}

\begin{abstract}
Main welding-technological properties of pure shielding gases and gas mixtures in consumable and nonconsumable welding of different materials were analyzed. It is outlined that knowledge of properties of shielding gas components allows their efficient selection from point of view of welding process optimizing, increase of quality indices and service properties of welded parts, improvement of conditions of work and rise of its efficiency as well as providing of environmental safety of the works. A conclusion is made based on given data that arc method will remain one of the leading technological processes of material joining in the near and far future. 34 Ref., 3 Tables, 3 Figures.
\end{abstract}

$\boldsymbol{K} \boldsymbol{e} \boldsymbol{y} \boldsymbol{w} \boldsymbol{O} \boldsymbol{d} \boldsymbol{s}:$ arc welding, consumable and non-consumable electrodes, pure gases, compositions of gas mixtures, welding methods, fields of application, materials to be welded

Developments of active gas-shielded arc welding methods using consumable and non-consumable electrodes have been stated at the E.O. Paton Electric Welding Institute in the thirties of the last century and are still continued. Development and wide industrial application of active gasshielded arc welding intensified when the method of consumable-electrode $\mathrm{CO}_{2}$ welding [1] was for the first time proposed and developed in the USSR. Before this, pore formation in the welds was the main obstacle for application of $\mathrm{CO}_{2}$ as a shielding atmosphere. The reason of porosity was boiling of weld pool metal due to emission of carbon monoxide as a result of its insufficient deoxidation. Application of welding wires with increased content of silicon such as Sv-08GS and Sv-08G2S type eliminated this disadvantage [2] and provided the possibility of wide application of carbon dioxide in welding production.

Further works, carried at the E.O. Paton Electric Welding Institute, allowed determining the conditions providing for the possibility of effective influence on nature of change of physical processes in discharge gap. As a result, new method of consumable-electrode shielded-gas pulsed arc welding (PAW) using program control of formation of each droplet of the consumable electrode, and, as a consequence, size and shape of the weld in all spatial positions $[3,4]$ was developed. Pulsed rise of arc current significantly affects nature of arc discharge and improve its stability, that allows consequently reducing low margin of the welding current which sup-

(c) B.E. PATON, S.T. RIMSKY and V.I. GALINICH, 2014 ports arcing. For example, welding of aluminum in argon using $1.6 \mathrm{~mm}$ diameter wire provides for stable PAW process at around $30 \mathrm{~A}$ current instead of 110-120 A. The low current margin of welding of stainless steel in argon using $2.0 \mathrm{~mm}$ diameter wire makes $130 \mathrm{~A}$ instead of 250-280 A in stationary arc welding. At that, a fine drop transfer of electrode metal is observed in all cases, that not only allow welding in all spatial positions, but also simplifing equipment for mechanized welding of different materials, reducing metal loss due to burn-off and sputtering, providing high mechanical properties of the weld metal and improving its formation [3, 5].

Developments of the E.O. Paton Electric Welding Institute in field of arc methods of welding attract specific attention of the scientists and experts from other countries and, in particular, form the basis for development of efficient compositions of shielding gas media and technology of production of critical designation structures.

Evolution of fusion welding as one of the most important technological processes in industry and building is tightly related with development of the procedures of molten metal shielding from air. Application of mixtures of argon with oxidizing gases $\mathrm{CO}_{2}$ and $\mathrm{O}_{2}$ was developed, based on new prospects of application of method of active gas-shielded welding of steel. The widest distribution received $\mathrm{Ar}+\mathrm{CO}_{2}$, $\mathrm{Ar}+\mathrm{CO}_{2}+\mathrm{O}_{2}$ and $\mathrm{Ar}+\mathrm{O}_{2}$ mixtures. Composition of Ar-based gas mixtures can include $0.5-8 \% \mathrm{O}_{2}$ and $3-25 \%$ $\mathrm{CO}_{2}$ [6] depending on class of steels to be welded.

Application of the oxidizing Ar-based gas mixtures in consumable-electrode welding allowed eliminating or reducing to minimum many wellknown disadvantages typical for welding in pure $\mathrm{CO}_{2}$, in particular, providing significant decrease 
of sputtering and spitting of electrode metal, improving weld formation, reducing specific consumption of wire per unit of weld length [7], rising weld metal mechanical properties and its resistance to nucleation and propagation of brittle fractures [8].

Developed at the E.O. Paton Electric Welding Institute automatic and semi-automatic machines for gas-shielded welding of high-volume parts are successfully used in many countries [35]. Thus, production of welding equipment showed on average 3-4 times increase and significant rise of quality of the parts.

Industrial application of consumable-electrode gas-shielded arc welding uniformly expands, and there are many reasons to believe that the same situation will take place in future. Analysis of reference data [7, 9-13] showed that the gas-shielded arc welding dominates among other methods of fusion welding. Besides, a tendency is preserved for change of manual stick electrode welding to mechanized methods. From this point of view, the perspective branches, which master new types of metal-intensive products and expect investments related with that, are automotive industry, aircraft industry, highspeed railway transport, and, to lesser degree, shipbuilding. The main factors, influencing volumes of application and range of used shielding gases, are change in variety of materials to be welded, high quality requirements to welded joints and structures, increase of efficiency of welding operations and acceptable indices of welding processes from point of view of hygiene and environment.

Typical structure of prime cost of welding works in consumable-electrode gas-shielded welding consists of expenses for shielding gas $(5 \%)$ and wire $(15 \%)$ plus labor expenses $80 \%$ $[14,15]$. Therefore, application of more expensive shielding gas (for example, Ar-based mixture of gases instead of $\mathrm{CO}_{2}$ ) can be fully justified, since increase of labor productivity provided as a result of such change (i.e. reduction of expenses for welders' salary) compensates rise of cost of shielding gas.

Process of welding in Ar-based gas mixtures, together with technological and environment advantages, is characterized by improved hygiene and environment indices in comparison with $\mathrm{CO}_{2}$ welding, since less amount of dust and toxic gases is emitted into the welder's breathing zone and air of workroom $[16,17]$. It is possible to reduce intensity of general and local ventilation, i.e. set capacities of ventilation installations and, respectively, expenses for electric power and servicing, due to decrease of the level of harmful emissions in welding and, consequently, sickness rate of the workers. Somewhat increased specific level of ozone emissions during welding in argon mixtures is not an obstacle for application of this process, since keeping of optimum modes of welding and application of simple protective means provide for a concentration of ozone in the welder's breathing zone below the level of maximum concentration limit [18].

Application of argon mixtures with oxidizing gases $\mathrm{O}_{2}$ and $\mathrm{CO}_{2}$ as shielding gases allows eliminating number of technological disadvantages, typical for process of welding in pure argon and carbon dioxide, thus, expanding area of application of mechanized consumable-electrode welding. Experience, accumulated at the E.O. Paton Electric Welding Institute and abroad, shows that such shielding mixtures are $\mathrm{Ar}+\mathrm{O}_{2}, \mathrm{Ar}+$ $+\mathrm{CO}_{2}$ and $\mathrm{Ar}+\mathrm{O}_{2}+\mathrm{CO}_{2}$, which are mainly used in welding of steels. Table 1 gives the methods of welding and compositions of shielding gases, used for welding of different materials.

Pure gases and their mixtures, indicted in this Table, have series of important welding-technological properties.

Carbon dioxide a long time was mainly used in the East European counties and developing countries due to its relatively low cost and availability. However, $\mathrm{CO}_{2}$ welding using commercial silicon-manganese wires has significant disadvantages such as increased level of sputtering and spitting of electrode metal, narrow and deep penetration of base metal with high bead, sometimes unsatisfactory mechanical properties of weld metal and, in particular, its impact toughness at negative temperatures. They became a reason of stable tendency to replace $\mathrm{CO}_{2}$ with Ar-based mixtures in these countries at recent time at the branches, where great attention is paid to weld metal and welded joint quality indices. Among industrialized countries, only Japan preserves high volumes of application of $\mathrm{CO}_{2}$ welding (around $70 \%$ of total scope of welding works, made by mechanized gas-shielded welding) [19]. Japan is the country with limited energy resources, therefore, it is obvious that the main direction of works on reduction of disadvantages of $\mathrm{CO}_{2}$ welding in Japan lies in improvement of power sources or application of new solid and flux-cored welding wires [19] because of increased energy consumption of argon production in comparison with $\mathrm{CO}_{2}$.

It should be noted that process of $\mathrm{CO}_{2}$ welding is very sensitive to the changes in mode parameters. Small diameter wire $(0.8-1.4 \mathrm{~mm})$ or low 
VIII INTERNATIONAL CONFERENCE «WELDING CONSUMABLES》

Table 1. Pure shielding gases and gas mixtures for welding of different materials

\begin{tabular}{|c|c|c|c|c|c|c|c|c|}
\hline \multicolumn{6}{|c|}{ Composition, vol.\% } & \multirow{2}{*}{$\begin{array}{l}\text { Welding } \\
\text { method }\end{array}$} & \multirow{2}{*}{$\begin{array}{l}\text { Field of } \\
\text { application }\end{array}$} & \multirow{2}{*}{ Material to be welded } \\
\hline Ar & $\mathrm{He}$ & $\mathrm{CO}_{2}$ & $\mathrm{O}_{2}$ & $\mathrm{H}_{2}$ & $\mathrm{~N}_{2}$ & & & \\
\hline \multicolumn{9}{|c|}{ Pure gases } \\
\hline \multirow[t]{2}{*}{100} & \multirow[t]{2}{*}{-} & \multirow[t]{2}{*}{-} & \multirow[t]{2}{*}{-} & - & - & TIG & 0 & $\begin{array}{l}\text { Copper, aluminum, titanium, molybdenum and other } \\
\text { non-ferrous, active and refractory metals and their } \\
\text { alloys, corrosion-resistant low- and high-alloy chromium } \\
\text { nickel steels }\end{array}$ \\
\hline & & & & - & - & MIG & $\boldsymbol{\nabla}$ & Non-ferrous metals and chromium-nickel steels \\
\hline- & 100 & - & - & - & - & TIG & O & $\begin{array}{l}\text { Copper, aluminum and other non-ferrous metals and } \\
\text { alloys }\end{array}$ \\
\hline \multirow[t]{2}{*}{-} & \multirow[t]{2}{*}{-} & \multirow[t]{2}{*}{100} & \multirow[t]{2}{*}{-} & - & - & \multirow[t]{2}{*}{ MAG } & 0 & Carbon and low-alloy steels \\
\hline & & & & - & - & & $\nabla$ & Stainless steels \\
\hline- & - & - & - & - & 100 & MAG & $\nabla$ & Copper and copper alloys \\
\hline \multicolumn{9}{|c|}{ Two-component mixtures } \\
\hline 70 & 30 & - & - & - & - & TIG & $\nabla$ & $\begin{array}{l}\text { Aluminum and other non-ferrous metals, low- and high- } \\
\text { alloy chromium-nickel steels }\end{array}$ \\
\hline $98-96$ & - & - & $2-4$ & - & - & MAG & $\nabla$ & Low- and high-alloy steels \\
\hline $90-92$ & - & - & $8-10$ & - & - & MAG & O & Carbon and low-alloy steels \\
\hline $97-98$ & - & $2-3$ & - & - & - & \multirow[t]{2}{*}{ MAG } & \multirow[t]{2}{*}{0} & Alloy and high-alloy steels \\
\hline $75-90$ & - & $10-25$ & - & - & - & & & Carbon and low-alloy steels \\
\hline $90-95$ & - & - & - & $5-10$ & - & MIG & $\nabla$ & High-alloy chromium-nickel steels \\
\hline $85-90$ & - & - & - & - & $10-15$ & MIG & $\boldsymbol{\nabla}$ & Copper and copper alloys \\
\hline \multicolumn{9}{|c|}{ Three-component mixtures } \\
\hline $50-69$ & $30-45$ & - & $1-5$ & - & - & MAG & $\boldsymbol{\nabla}$ & High-alloy chromium-nickel steels \\
\hline $55-67$ & $30-40$ & $3-5$ & - & - & - & MAG & $\nabla$ & Increased-strength high-alloy chromium-nickel steels \\
\hline $70-87$ & - & $10-25$ & $3-5$ & - & - & MAG & O & Carbon and low-alloy steels \\
\hline 65 & 25 & - & - & 10 & - & MAG & $\nabla$ & Corrosion-resistant high-alloy chromium-nickel steels \\
\hline 60 & 30 & - & - & - & 10 & MIG & $\nabla$ & Copper and copper alloys \\
\hline \multicolumn{9}{|c|}{ Four-component mixtures } \\
\hline 76 & 20 & 3 & - & 1 & - & MAG & $\mathrm{O}$ & Corrosion-resistant high-alloy chromium-nickel steels \\
\hline 65 & 26.5 & 8 & 0.5 & - & - & $\begin{array}{l}\text { MAG } \\
\text { TIME }\end{array}$ & $\boldsymbol{\nabla}$ & $\begin{array}{l}\text { Increased-strength low-alloy fine grain manganese steels } \\
\text { and chromium-nickel steels }\end{array}$ \\
\hline
\end{tabular}

currents (with short circuiting) and high currents (using immersed arc) are preferable for $\mathrm{CO}_{2}$ welding in order to receive satisfactory weld formation and reduce metal loss for sputtering. The average modes, showing maximum sputtering, should be eliminated. For example, unfavorable modes for $2.0 \mathrm{~mm}$ diameter wire lie in the range of $280 \mathrm{~A} \leq I_{\mathrm{w}} \leq 400 \mathrm{~A}$ and $28 \mathrm{~V} \leq U_{\mathrm{a}} \leq 32 \mathrm{~V}$. Unfortunately, such recommendations are difficult to fulfill on practice, since average currents and wires of $1.0-1.2 \mathrm{~mm}$ diameter are, in particular, necessary for providing of high efficiency and optimum heat input in welding of metals of average thicknesses.

Argon is the most widely used component of the shielding gas mixtures, mainly, in TIG weld- ing of non-ferrous, active and refractory metals $(\mathrm{Cu}, \mathrm{Al}, \mathrm{Ni}, \mathrm{Mo}$ and others) and their alloys as well as alloy and high-alloy steels. Argon MIG welding of carbon and low-alloy steels does not find noticeable application due to unsatisfactory transfer of electrode metal through arc and formation of undercuts during its wandering over metal surface. At that, the welds are susceptible to nitrogen, hydrogen and carbon oxide induced pore formation. Low potential of argon ionization $(15.75 \mathrm{eV})$ provides for stable arcing at low voltage, facilitate its excitation and rise stability. Arc plasma in argon has high-energy internal core and outer zone with low level of emitted energy that results in undesirable formation of fingertype penetration (Figure 1, d) [20]. 


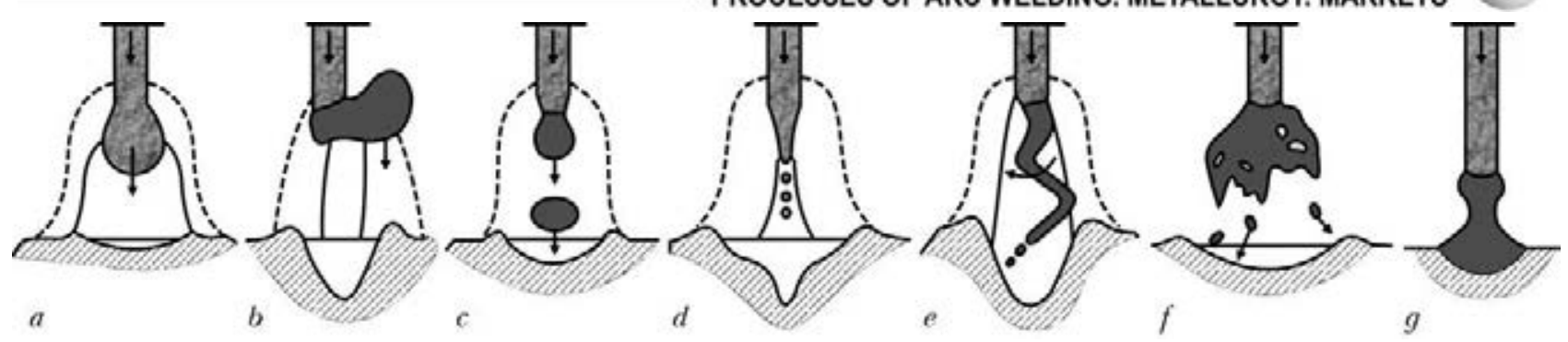

Figure 1. Effect of type of metal transfer on shape of penetration according to IIW classification [20]: $a-$ drop; $b-$ globular; $c$ - fine drop; $d-$ spray; $e-$ spray-rotation; $f$ - with drop explosion; $g$ - short circuiting

Helium, among gases used in welding, takes the second place in density $\left(0.178 \mathrm{~kg} / \mathrm{m}^{2}\right)$ after hydrogen $\left(0.083 \mathrm{~kg} / \mathrm{m}^{2}\right)$. In comparison with argon $\left(1.784 \mathrm{~kg} / \mathrm{m}^{2}\right)$ helium has higher thermal conductivity, that provides for uniform energy distribution on arc column section allowing producing deep and wide parabolic shape of penetration and small weld reinforcement with smooth transfer to base metal. High potential of helium ionization $(24.58 \mathrm{eV})$ requires keeping of increased arc voltage in comparison with welding in argon at the same arc length and welding current. Therefore, helium is used as a rule in mixtures with argon for welding of aluminum and other materials in the cases when high energy concentration in the weld zone is necessary.

World market of helium was small and stable for the long time. However, novel developments of the technology of gas-shielded welding revealed new prospects for expanding its application. This is explained by usage of high-production processes of welding of different materials in He-containing gas mixtures, for example, $\mathrm{Ar}+$ $+\mathrm{He}, \mathrm{Ar}+\mathrm{He}+\mathrm{CO}_{2}[9-12,21-23]$, as well as metal electrode transferred-arc welding in ionized shielding gases with high energy density (TIME process) [24, 25]. Usage of such processes, providing for application of the shielding gas of increased price, is, in particular, relevant for countries with high level of labor remuneration at industry, since increase of price of the shielding gas is compensated by reduction of share of expenses in a general prime cost of welding works due to obvious increase of welder's work productivity.

Oxygen, as one of the components of gas mixtures, is used in small quantities (from fractions of percent to several percent) for activation of metallurgical processes in welding of steel as well as can be present in form of additive in amount of 3-5 vol.\% used as one of the mixture components of so-called raw argon (i.e. purged from nitrogen additives and other gases to sufficient level in air separation machine in process of production, but not cleaned of oxygen).

$\mathrm{Ar}+\mathrm{CO}_{2}$ mixtures. Addition of oxygen can improve process of welding and remove some dis- advantages related with application of pure argon. Addition of 3-5\% $\mathrm{O}_{2}$ to argon and usage of welding wire, alloyed with silicon and manganese, allow increasing resistance to pore formation in the welds on killed, semikilled and rimmed steel. Presence of oxygen in argon virtually does not change arc shape, however significantly improves stability of arcing and provide positive effect on nature of electrode metal transfer and promote rise of number of drops transferred per unit of time due to reduction of its surface tension.

Fine drop (spray) metal transfer is achieved at lower value of welding current with virtually no sputtering in comparison with application of pure argon.

Content of oxygen in $\mathrm{Ar}+\mathrm{O}_{2}$ mixture can vary from $0.5-5.0 \%$. Optimum content of oxygen in mixture for welding of carbon and low-alloy steels makes 3-5\%. This mixture provides for good weld appearance and high level of weld metal mechanical properties, in particular, impact toughness at negative temperatures. More than $5 \%$ content of oxygen rapidly rises loss of alloying elements, and technological characteristics of welding process show no changes. At the same time, $\mathrm{Ar}+\mathrm{O}_{2}$ mixture as well as pure $\mathrm{CO}_{2}$ are not used in nonconsumable-electrode welding due to electrode breakdown and contamination of weld metal by tungsten oxides.

$\mathrm{Ar}+\mathrm{O}_{2}$ mixtures, containing minimum amount of oxygen (1-2\%), have limited application in welding of ferrite steels and are mainly used for welding of austenite steels. Firstly, it can be explained by the fact that they are produced by mixing of expensive pure gases and, secondly, that the mixtures with low content of oxygen have the same disadvantages in welding as pure argon (narrow penetration of the base metal in weld root, low weld pore formation resistance, wandering of the arc across welded edges, resulting in undercuts and lacks of fusion, intensive heat and light irradiation of the arc, emission of ozone of more than the allowable concentration in the welder's breathing zone). All these disadvantages can be specifically well 
observed in welding with spray transfer and sufficiently long arc, therefore, application of argon-oxygen mixture with small additions of oxygen can not be technically and economically approved for welding of carbon and low-alloy steels.

$\mathrm{Ar}+\mathrm{CO}_{2}$ mixtures. Efforts made in discovering a shielding medium, which could combine advantages of argon, carbon dioxide and argonoxygen mixture, promoted application of mixtures of these gases.

Shape of the arc and nature of electrode metal transfer during welding in $\mathrm{Ar}+\mathrm{CO}_{2}$ mixtures significantly depend on mixture composition. The same mode of welding in mixtures with different content of $\mathrm{CO}_{2}$ provides different electrode metal transfer, namely, nonshort-circuit drop metal transfer (Figure 1, $a$ ) or transfer with short-circuiting of arc gap (Figure 1,g), fine drop transfer (Figure 1,c) and spray transfer (Figure 1, $d$ ). The shape of base metal penetration changes and finger-type penetration escapes (see Figure $1, d$ ) in $20 \% \mathrm{CO}_{2}$ content and more at currents above the critical value. If the mixture includes more than 35-40\% $\mathrm{CO}_{2}$, the process in many aspects will be similar to welding in pure $\mathrm{CO}_{2}$, however level of sputtering, at that, is lower.

Improvement of weld formation in use of $\mathrm{Ar}+$ $+20-25 \% \mathrm{CO}_{2}$ mixtures is observed for wide range of modes. Reinforcement height is significantly lower than in $\mathrm{CO}_{2}$ welding, the bead has smooth transfer to the base metal, and range of the currents, at which spray (fine drop) transfer takes place, promotes formation of fine-rippled surface as in submerged arc welds (Figure 2). Favorable weld shape, small height of reinforcement and decreased level of loss of electrode metal for sputtering provide for obvious reduction of consumption of electrode wire per unit of weld length.

The recommendations on optimum composition of $\mathrm{Ar}+\mathrm{CO}_{2}$ mixtures from the foreign com-

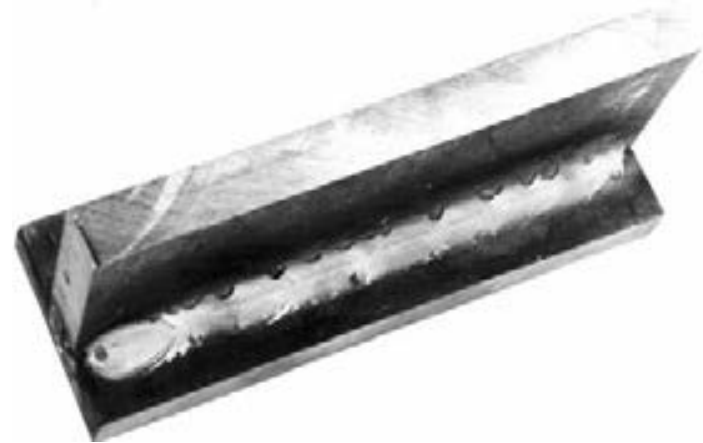

Figure 2. Appearance of fillet weld made in $\mathrm{Ar}+20 \% \mathrm{CO}_{2}$ mixture using Sv-08G2S wire of $1.2 \mathrm{~mm}$ diameter at $I_{\mathrm{W}}=$ $=260 \mathrm{~A}$ and $U_{\mathrm{a}}=28 \mathrm{~V}$ panies, manufacturing gas mixtures, are controversial. Obviously, it is mainly caused by aggressive competition at sales market and patent matters as well as differences in chemical composition of used steels and welding wires. $\mathrm{Ar}+10^{-}$ $15 \% \mathrm{CO}_{2}$ mixture is widely advertised in Europe [9, 11, 12]. However, accumulated experience showed that $\mathrm{Ar}+20 \% \mathrm{CO}_{2}$ mixture should be considered the optimum one. It has better combination of technological and metallurgical properties and its application can help to eliminate finger-type penetration, resulting in lacks of fusions and pores typical for argon, as well as narrow and deep penetration, dangerous from point of view of crack formation in the welds, characteristic for carbon dioxide.

Structural steel joints, welded in shielding Ar-based gas mixtures using standard wires, traditionally used for $\mathrm{CO}_{2}$ welding ( $\mathrm{Sv}-08 \mathrm{G} 2 \mathrm{~S}$ and Sv-08GS on GOST 2246-70), differ by high indices of mechanical properties (Table 2) [7]. The values of impact toughness of weld metal at negative temperatures as well as indices of resistance of weld metal, produced in $\mathrm{Ar}+\mathrm{CO}_{2}$ mixture, to nucleation and propagation of brittle fracture [8] should be particularly noted. Improvement of mechanical and service properties of the welds and joints, produced in Ar-based mixtures, take place as a result of reduction of oxygen content in the welds, formation of favorable microstructure of the metal with domination of acicular ferrite and satisfactory formation of the welds. The indices of cold and crack resistance of welds at the level of values of joints, welded at increased specific heat input using argon mixtures, can not be received during $\mathrm{CO}_{2}$ welding under similar conditions (Figure 3) [7, 26, 27]. In general, our data and results published by other researchers $[17,28]$, indicate that the indices of mechanical properties of weld metal, produced in $\mathrm{Ar}-$ based gas mixtures, correspond with the requirements made to the joints and structures operating under conditions of negative temperatures, dynamic loads and other unfavorable factors.

The disadvantage of $\mathrm{Ar}+\mathrm{CO}_{2}$ mixture is its high price in comparison with pure $\mathrm{CO}_{2}$ and $\mathrm{Ar}+$ $+\mathrm{O}_{2}$ mixture. It is promoted by the fact that the mixture is produced from pure gases and in contrast to argon-oxygen mixture it can not be produced directly by air separation using air-separation units. Application as an initial component of «raw argon», containing up to $5 \% \mathrm{O}_{2}$, is technically and technologically acceptable method for cheapening of argon mixtures with $\mathrm{CO}_{2}$.

$\mathrm{Ar}+\mathrm{O}_{2}+\mathrm{CO}_{2}$ mixtures have found wide distribution in Germany and Great Britain [9, 
11, 12, 14]. «Coxogen» mixture $\left(\mathrm{Ar}+5 \% \mathrm{O}_{2}+\right.$ $+15 \% \mathrm{CO}_{2}$ ) has lower oxidizing power and better technological properties than pure $\mathrm{CO}_{2}$. Welding of carbon and low-alloy steels using $\mathrm{Mn}$ - and Si-deoxidized wire provides such advantages as lower sputtering of electrode metal, better weld appearance, lower susceptibility of welds to formation of pores and hot cracks in comparison with $\mathrm{CO}_{2}$ welding. The mechanical properties of weld metal and welded joint are the same as during welding in $\mathrm{Ar}+20-25 \% \mathrm{CO}_{2}$ mixture and impact toughness of the welds, made in this mixture, is higher.

Since consumable-electrode gas-shielded welding process dominates in Europe, the main attention is paid to the problem of selection of shielding gas composition. The criteria for its optimizing include level of sputtering, weld spatters and slag on the surface of base metal, and formation of the weld (shape of penetration and appearance). Welding of carbon and low-alloy steels using low-oxidizing Ar-based mixtures with small content of oxidizing gases $\left(1-4 \% \mathrm{O}_{2}\right.$ and up to $10 \% \mathrm{CO}_{2}$ ) are proposed [28] based on approaches mentioned above. It should also be considered that all the disadvantages of pure argon, indicated above, appear during welding of these steels in low-oxidizing Ar-based mixtures.

Low-oxidizing Ar-based mixtures cannot be considered as general purpose shielding gases for welding of carbon and low-alloy steels in terms of Ukrainian industry, since the most widespread in our country wires Sv-08G2S and Sv-08GS have higher level of alloying in comparison with wires of similar designation (SG-1, SG-2, SG-3, DIN 8559) applied in Europe. Besides, European welding production uses small diameter wires and milder welding modes in comparison with that used in Ukraine. The accumulated experience showed that it is good to limit the range of shielding gases of domestic welding production by one or two compositions of universal designation.

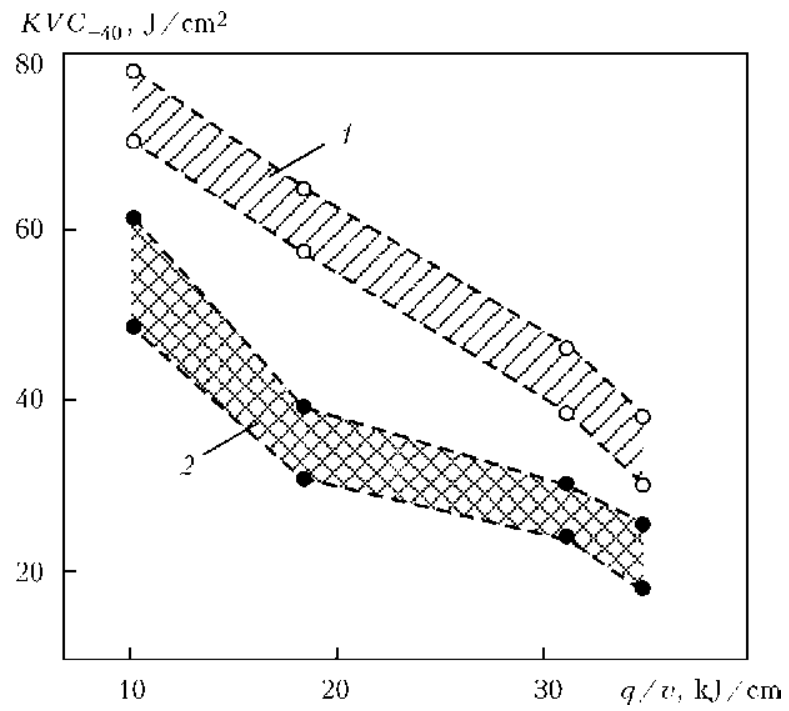

Figure 3. Effect of welding heat input on impact toughness of weld metal made on 09G2S steel using Sv-08G2S wire in $\mathrm{Ar}+20 \% \mathrm{CO}_{2}$ mixture (1) and pure argon (2)

$\mathrm{Ar}+20-25 \% \mathrm{CO}_{2}$ and $\mathrm{Ar}+3-5 \% \mathrm{O}_{2}+20-$ $25 \% \mathrm{CO}_{2}$ belong to such wide spread mixtures. They have optimum combination of welding characteristics, reasonable price and allow solving most of technological tasks during mechanized welding of general purpose steels even when the welders violate indicated mode parameters.

Welding in argon mixtures in contrast to $\mathrm{CO}_{2}$ welding provides for the possibility of application of pulsed-arc process [29, 30] with controlled fine drop transfer and frequency of drop detachment corresponding to frequency of application of current pulses. The fine drop transfer takes place at lower average value of the welding current in comparison with conditions without pulse application (Table 3). Using of PAW allows utilizing the wire of the same diameter for many variants of technology, whereas welding without pulses usually provides for application of different diameter wire depending on thickness of metal to be welded, its thermal-physical characteristics, spatial position of the weld and other indices.

Table 2. Mechanical properties of joints from low-alloy structural steels produced in $\mathrm{Ar}+20 \% \mathrm{CO}_{2}$ mixture using Sv-08G2S wire at different modes of welding [7]

\begin{tabular}{|c|c|c|c|c|c|c|c|c|c|c|}
\hline \multirow{2}{*}{$\begin{array}{c}\text { Base metal } \\
\text { (thickness, mm) }\end{array}$} & \multirow{2}{*}{$\begin{array}{c}\text { Wire } \\
\text { diameter, } \\
\mathrm{mm}\end{array}$} & \multirow{2}{*}{$I_{\mathrm{w}}, \mathrm{A}$} & \multirow{2}{*}{$U_{\mathrm{a}}, \mathrm{V}$} & \multirow{2}{*}{$\sigma_{y}, \mathrm{MPa}$} & \multirow{2}{*}{$\sigma_{\mathrm{t}}, \mathrm{MPa}$} & \multirow{2}{*}{$\delta_{5}, \%$} & \multirow{2}{*}{$\psi, \%$} & \multicolumn{3}{|c|}{$K C V, \mathrm{~J} / \mathrm{cm}^{2}$, at $T,{ }^{\circ} \mathrm{C}$} \\
\hline & & & & & & & & +20 & -20 & -40 \\
\hline 09G2S (12) & 2.0 & $400-420$ & $30-32$ & 390 & 550 & 26 & 63 & 145 & 67 & 47 \\
\hline 15S2AF (16) & 1.6 & $340-360$ & $28-30$ & 556 & 678 & 26 & 60 & 105 & 51 & 46 \\
\hline 10KhSND (20) & 2.0 & $380-410$ & $28-30$ & 540 & 650 & 28 & 62 & 145 & 66 & 44 \\
\hline 09G2 (20) & 1.6 & $360-390$ & $28-29$ & 486 & 592 & 29 & 69 & 153 & 81 & 57 \\
\hline
\end{tabular}


Table 3. Critical welding current of transition to spray metal transfer during welding in $\mathrm{Ar}+20 \% \mathrm{CO}_{2}$ mixture using $\mathrm{Sv}$ 08G2S wire

\begin{tabular}{||c|c|c|c|}
\hline \multirow{2}{*}{$\begin{array}{c}\text { Wire diameter, } \\
\text { mm }\end{array}$} & \multicolumn{3}{|c|}{$I_{\mathrm{w}}, \mathrm{A}$} \\
\cline { 2 - 4 } & $\begin{array}{c}\text { Reversed } \\
\text { polarity }\end{array}$ & $\begin{array}{c}\text { Straight } \\
\text { polarity }\end{array}$ & PAW \\
\hline 1.0 & 240 & - & 160 \\
\hline 1.2 & 260 & 350 & 180 \\
\hline 1.4 & 280 & 380 & 210 \\
\hline 1.6 & 340 & 420 & 240 \\
\hline 2.0 & 400 & 460 & - \\
\hline
\end{tabular}

Transfer to new economy relationships and structures together their development in Ukrainian industry will expand fields of application of mechanized consumable electrode welding in Arbased oxidizing mixtures instead of pure $\mathrm{CO}_{2}$. However, data on application of gas mixtures in welding of steels are unmatched, and they are difficult to use in practical activity. Therefore, summary of data necessary for application of the most widespread mixture of $\mathrm{Ar}+\mathrm{CO}_{2}$ in mechanized welding of steels are given in the recommendation tables [31].

The largest technical-economical effect of steel welding in Ar-based shielding mixtures is provided in the following branches:

- production of metal structures, which should have no weld spatters according to work conditions;

- production of metal structures of critical designation, being operated at negative temperatures and alternating dynamic loads;

- multipass welding of fillet and butt joints of heavy-plate metal;

- increased rate welding of small section welds;

- welding of parts using robots and automatic machines on automated assembly lines.

$\mathrm{Ar}+\mathrm{He}+\mathrm{CO}_{2}$ mixtures, with argon as the main component, are used in stationary and pulsed arc welding, and mixtures having predominate content of helium (60-80\%) are applied in short-circuiting arc welding. Foreign publications [21-23,32] consider different compositions of gas mixtures with helium (vol.\%: $\left.\left.(69-55) \mathrm{Ar}+(40-30) \mathrm{He}+(3-5) \mathrm{CO}_{2}\right)\right)$, providing good technological indices, in particular, rise of efficiency in thick metal welding, deep and wide penetration of base metal, improvement of formation and appearance of the welds. The main peculiarity of welding in $\mathrm{Ar}+\mathrm{He}+\mathrm{CO}_{2}$ mixtures is high process efficiency at modes with sprayrotation metal transfer (see Figure 1,e). Such a transfer takes place in using of $1.0-1.2 \mathrm{~mm}$ di- ameter wire, mechanism of its feeding of up to $50 \mathrm{~m} / \mathrm{min}$ rate and power source with good dynamic characteristics [22, 33].

$\mathrm{Ar}+\mathrm{He}+\mathrm{CO}_{2}+\mathrm{O}_{2}$ mixtures require special technology, power sources and mechanisms of wire feed. Thus, TIME-process [24, 25, 33] uses the gas mixture (vol.\%: $65 \mathrm{Ar}+26.5 \mathrm{He}+$ $+8 \mathrm{CO}_{2}+0.5 \mathrm{O}_{2}$ ) providing high speed of wire melting (up to $25 \mathrm{~kg} / \mathrm{h}$ ) with $50 \mathrm{~m} / \mathrm{min}$ feed rate at welding current around $600 \mathrm{~A}$. There are also high-productive methods such as Rapid Arc and Rapid Melt [10, 11, 32] which are carried out in shielding mixtures with helium (vol.\%: (60-65) $\left.\mathrm{Ar}+(25-30) \mathrm{He}+10 \mathrm{CO}_{2}\right)$. Their application provides for exceeding of classical limit of wire feed $20 \mathrm{~m} / \mathrm{min}$ and support different types of electrode metal transfer, including spray-rotation (see Figure 1,e).

Rigid limitation on composition of the shielding medium, provided by technological recommendations of TIME-process developers [23, 33], have no grounds since similar indices of efficiency and quality can be received using cheaper and simpler in production Ar-based mixtures without helium, for example, $\mathrm{Ar}+\mathrm{CO}_{2}+\mathrm{O}_{2}$, and by thorough selection and correction of the mode parameters [11, 14, 34].

Many gas-shielded arc welding methods are known at present time, using which the same works can be fulfilled. However, technical-economical results obtained at that will vary depending on production conditions and structure peculiarities. Each of the welding methods has specific technological capabilities and can be used for certain type of welding works, therefore, selection of optimum composition of shielding gas and method of welding requires complete understanding of peculiarities and capabilities of each of the methods and their consideration based on specific production conditions. Significant influence at that can have mechanization and automation of the welding processes, in particular, taking into account a wide range of existing at present time types of manipulators and pozitioners as well as robots and computer-controlled regulation systems.

1. Lyubavsky, K.V., Novozhilov, N.M. (1953) Consumable-electrode shielded-gas welding. Avtogen. Delo, 1, 4-8.

2. Novozhilov, N.M., Sokolova, A.M. (1958) Development of electrode wires for $\mathrm{CO}_{2}$ welding of low-carbon and low-alloy steels. Svarochn. Proizvodstvo, 7, 10-14.

3. Paton, B.E., Potapievsky, A.G., Podola, N.V. (1964) Consumable electrode pulsed arc welding with program control of process. Avtomatich. Svarka, 1, 1-6.

4. Paton, B.E., Voropaj, N.M., Buchinsky, V.N. et al. (1977) Control of arc welding process by programming of electrode wire feed rate. Ibid., 1, 1-5, 15. 
5. Paton, B.E., Lebedev, A.V. (1988) Control of melting and electrode metal transfer in $\mathrm{CO}_{2}$ welding. Ibid., 11, 1-5.

6. Paton, B.E., Kirsanov, A.V., Podgaetsky, V.V. et al. Shielding gas mixture. USSR author's cert. 448106 Int. Cl. B 23 K $35 / 38$. Prior. 26.06.72. Publ. 30.10.74.

7. Svetsinsky, V.G., Rimsky, S.T., Galinich, V.I. (1994) Welding of steels in shielding argon-based gas mixtures on in industry of Ukraine. Avtomatich. Svarka, 4, 41-44.

8. Svetsinsky, V.G., Rimsky, S.T., Kirian, V.I. (1992) Evaluation of fracture toughness of welds made in shielding gases and by submerged-arc process. Ibid., 8, 16-19.

9. Lucas, W. (1992) Choosing a shielding gas. Pt 2. Weld. and Metal Fabr., 6, 269-276.

10. Dilthey, U., Reisgen, U., Stenke, V. et al Schutzgase zum MAGM-Hochleistungsschweissen. Schweissen und Schneiden, 47(2), 118-123.

11. Dixon, K. (1999) Shielding gas selection for GMAW of steels. Weld. and Metal Fabr., 5, 8-13.

12. Salter, G.R., Dye, S.A. (1971) Selecting gas mixtures for MIG welding. Metal Constr. and British Welding J., 3(6), 230-233.

13. Cresswell, R.A. (1972) Gases and gas mixtures in MIG and TIG welding. Weld. and Metal Fabr., 40(4), 114-119.

14. Ameye, M. (2011) Einfluss der verschiedenen Schutzgase im Zusammenwirken mit Schweissverfahren und Werkstoffen. Der Praktiker, 7, 271-273.

15. Kajdalov, A.A., Gavrik, A.N. (2011) Efficiency of application of shielding gas mixtures in arc welding of steels. Svarshchik, 4, 28-31.

16. Press, H., Florian, W. Formation of toxic substances in gas welding. Pt 2: Amount of toxic substances formed in the gas shielded welding processes MAG, MIG and GTA. IIW Doc. VIII-880-80.

17. Haas, B., Pomaska, H.U. (1980) Influence of process specific welding parameters on fume generation in solid wire GMA (MAG) welding. In: Proc. of IIW Col. on Welding and Health (Estoril, Portugal, 8 July, 1980), 8.

18. Levchenko, O.G. (1986) Influence of shielding gas composition and welding parameters on total emission of welding aerosol. Avtomatich. Svarka, 1, 73-74.
19. Kosiishi, F. (2007) Advanced welding consumables. J. JWS, 76(1), 61-64.

20. Stenbacka, N., Persson, K.-A. (1989) Shielding gases for gas metal arc welding. Welding J., 11, 41-47.

21. Lyttle, K., Stapon, G. (2005) Simplifying shielding gas selection. Practical Welding Today, 1, 22-25.

22. Ernst, M. (1999) Lichtbogen stabil gehalten. Produktion, 8, 23.

23. Urmston, S. (1996) Quality - all things to all welders. Weld. and Metal Fabr., 64(4), 150-152.

24. Church, J.G. Welding system. Pat. 4.463.143 USA. Publ. July 1984.

25. Lahnsteiner, P. (1991) T.I.M.E. - Process ein neues MAG-Schweissverfahren. Schweisstechnik, 12, 182-186.

26. Rimsky, S.T. (2011) Control of properties of the weld metal by regulating the level of oxidation of the weld pool in gas-shielded welding. The Paton Welding J., 12, 16-19.

27. Roshchupkin, N.P., Bliznets, N.A., Svetsinsky, V.G. et al. (1984) Experience of industrial application of shielding argon-based gas mixtures by All-Union plants «Soyuzstalkonstruktsiya». Avtomatich. Svarka, 3, 51-53.

28. (2001) SAGOS 3: Schutzgas fuer zwei Werkstoffgruppen. Stahlmarkt, 51(11), 66.

29. Pfeiffer, G. (1989) Zuend- und Spritzeruntersuchungen beim MAG-Impulsschweissen. ZIS-Mitteilungen, 31(6), 545-549.

30. Rimsky, S.T., Svetsinsky, V.G., Shejko, P.P. et al. (1993) Consumable electrode pulsed arc welding of low-alloy steels in argon mixture with $\mathrm{CO}_{2}$. Avtomatich. Svarka, 2, 38-41.

31. Rimsky, S.T. (2006) Manual on technology of shielded-gas mechanized welding. Kiev: Ekotekhnologiya.

32. (2005) Das Schutzgas machts. Blech. Rohre Profile, $52(8 / 9), 28-30$.

33. Church, J.G., Imaizumi, H. Welding characteristics of a new welding TIME-process. IIW Doc. XII-1199.

34. Oeteren, K.-A. (1992) «Neues Schutzgas» metal-aktivgasgeschweisst - ein wirtschaftliher Vorteil? Der Praktiker, 2, 90-94.

Received 11.04.2014 